\title{
13 Tapen in de praktijk
}

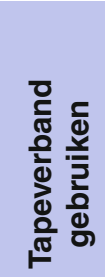

Ondanks alle individuele nuances verdient het aanbeveling bij het tapen ook bepaalde handmatige automatismen en een vaste volgorde van handelingen aan te leren. Op die manier is het mogelijk de benodigde zekerheid bij het aanleggen te ontwikkelen en tijdverlies te vermijden.

\section{Praktische volgorde bij het tapen}

- Anatomische structuur en tapemateriaal bekijken en voelen (zichten tastdiagnose van weefsel en tapemateriaal);

- tapelengte inschatten en afrollen, dan overeenkomstig de anatomische situatie afmeten;

- tape afscheuren (voorafgaand aan of - voor ervaren tapers - tijdens het aanleggen);

- tape overeenkomstig de fysiologische en anatomische verlooprichting met spanning aanleggen;

- modelleren van het tapeverband (handmatig, zodat optimaal contact wordt gemaakt met de huid of de onderlaag);

- bekijken (inspectie van het voltooide tapeverband in bewegingsfunctie en onder belasting).
Algemene aanpak

Bekijken;

Palperen;

Inschatten;

Afrollen;

Afmeten;

Afscheuren;

Aanleggen;

Modelleren;

Bekijken.

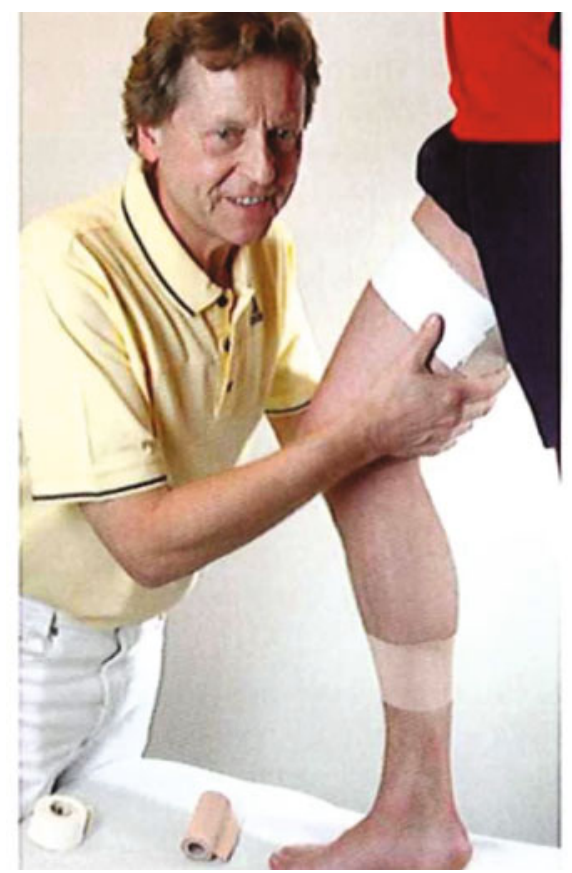

Palperen

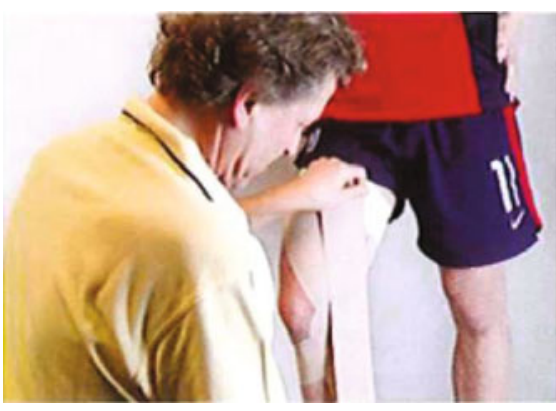

Inschatten

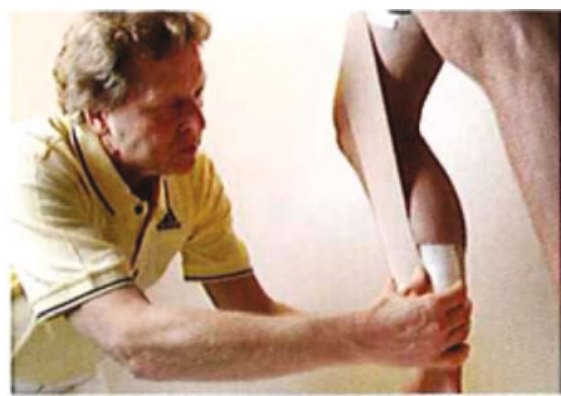

Aanleggen

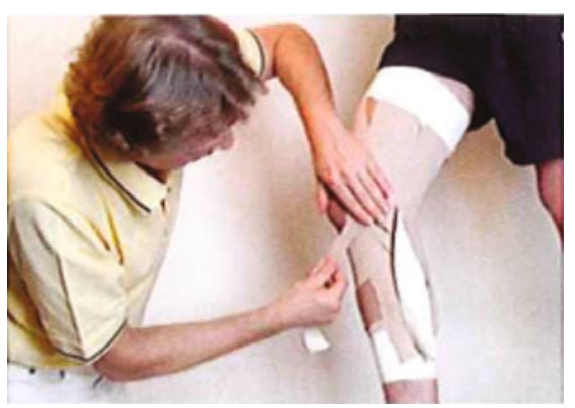

Modelleren 